UDC: 378.141.4:615.1

DOI: 10.32345/USMYJ.1.2021.13-21

\title{
PHARMACY STUDY PLANS IN VISEGRAD GROUP COUNTRIES AND UKRAINE: A COMPARATIVE ANALYSIS
}

\author{
Devinyak Oleg, Stan Iryna, Syatynya Viktoriya, Deyak Yaroslava, Lytvyn Olena, \\ Kachur Ivan \\ Uzhhorod National University, Ukraine
}

\begin{abstract}
Careful design of study plan is a key element of any successful educational program. Till 2018 Ministry of Health of Ukraine regulated the structure of Pharmacy study plans through the adoption of unified Ministerial study plan. Now the responsibility of educational programs and corresponding study plans design in Ukraine is fully transferred to universities. The purpose of this study is to compare the structure and content of pharmacy study plans in Visegrad Group countries with the most recent unified Pharmacy study plan in Ukraine. Methods. The official documents of Warsaw Medical University, Jagiellonian University in Krakow, Charles University, University of Veterinary and Pharmaceutical Sciences Brno, Comenius University, University of Veterinary Medicine and Pharmacy in Kosice, Semmelweis University and University of Debrecen were studied and data on required courses and corresponding ECTS credits extracted and compared with Ukrainian study plan. Results. Ukrainian unified study plan in Pharmacy pays much more attention to Humanity, Social and Economics section (9 ECTS credits plus 6 ECTS credits of Foreign Language), Computer and IT skills (8 ECTS credits), Hygiene and Ecology (3 ECTS credits), Life Safety, Labor Safety and Bioethics (6 ECTS credits in total), Extreme Medicine and Military Training (6 ECTS credits in total), Toxicological and Forensic Chemistry (4 ECTS credits), Organization and Economics of Pharmacy, Pharmaceutical Management and Marketing (12 ECTS credits in total) as compared to foreign universities. While natural science courses receive less ECTS credits in Ukraine, and some courses in rapidly evolving sciences like Molecular Biology, Immunology or Clinical Biochemistry are significantly underrepresented. Conclusions. The Pharmacy study plans of Visegrad Group universities show greater similarity with each other and tend to differ from the Ukrainian Ministerial study plan. The necessary steps to harmonize Pharmacy study plans of Ukrainian universities with V4 countries include the introduction of Molecular Biology, Immunology, Clinical Biochemistry courses, and strengthening the basic medical and chemical science courses like Human Anatomy and Physiology, Organic Chemistry, Analytical Chemistry, Pharmacology, Medicinal and Pharmaceutical Chemistry.
\end{abstract}

Key words: study plans, curriculum design, pharmacy education, Visegrad Group countries, ECTS credits

Introduction Proper pharmaceutical education is a cornerstone of high-quality pharmaceutical care and patient counselling in any healthcare system. Pharmacists' roles are constantly evolving aiming at the satisfaction of changing health needs of patients. Pharmaceutical education should follow current trends in up-to-date pharmaceutical practice in order to prepare qualified workforce capable to fulfil a broad range of responsibilities. In order to address the issue of pharmaceutical education on an international level the WHO UNESCO FIP Pharmacy Education Taskforce have been raised as a collaborative effort of global institutions (Anderson et al., 2009). The FIP statement of policy on good pharmacy education practice (Federation, 2000) is one of the first global recommendations concerning the design, scope and delivering of pharmaceutical educational programs. It provides the following areas as relevant parts of pharmaceutical curriculum: 
- biological systems, the chemistry of drugs and other constituents of medicines, pathophysiology and disease states and the interaction between medicines and biological systems,

- dosage form design and development,

- the actions and uses of medicines and other relevant products,

- the laws governing the practice of pharmacy and the sale and supply of medicines,

- the principles governing ethical conduct as set out in FIP's Code of Ethics for Pharmacists (1997) and the relevant national Code,

- safety and risk management,

- pharmaco-epidemiology and pharmaco health-economics,

- an introduction to the practice of pharmacy in community and hospital pharmacies, industrial, academic, and where appropriate, clinical biology settings including an introduction to the relevant aspects of the social and behavioral sciences, leading to competency in delivering patient care,

- an introduction to the effective management of resources (human, physical, fiscal and time),

- an introduction to guidelines governing good practices in manufacturing, distribution and laboratories.

The Directive 2005/36/EC of the European Parliament and of the Council of 7 September 2005 on the recognition of professional qualifications (European Parliament, 2005) lists the obligatory courses for professional education in Pharmacy: Plant and Animal Biology, Physics, General and Inorganic Chemistry, Organic Chemistry, Analytical Chemistry, Pharmaceutical Chemistry, including analysis of medicinal products, General and Applied Biochemistry (medical), Anatomy and Physiology, Medical Terminology, Microbiology, Pharmacology and Pharmacotherapy, Pharmaceutical Technology, Toxicology, Pharmacognosy, Legislation and, where appropriate, Professional Ethics.

The FIP Global Education Report, 2013 was the first publication that summarized the current state of pharmaceutical education worldwide (Anderson et al., 2014). Now it serves as a baseline that helps to identify recent changes in pharmaceutical education globally. In 2017, the FIP Nanjing Statements on Pharmacy and
Pharmaceutical Sciences Education has provided a solid basis for the development or further improvement of national strategies and standards of pharmaceutical education (Law et al., 2019). Considering the curricular structure, the Nanjing Statements give the following recommendations:

- The proper balance of science and practice should be established and taught: biomedical sciences, including pathophysiology, pharmacology and pharmacotherapy, should be distributed throughout the curriculum and should be taught in the context of patients and medicines

- Aspects of pharmaceutical chemistry, pharmaceutical technology and pharmaceutical analysis should be included in the curriculum to present the processes related to the development, production and registration of medicinal products. Students should be taught both basic pharmaceutical sciences and the use of medicines in the context of the patient care

- Pharmaceutical regulatory sciences should be included as part of the curriculum to provide knowledge and skills to students relevant to ensure the quality and safety of medicines and appropriate professional practice.

- Besides the basic sciences, clinical, social and administrative sciences are fundamental when they support learning about patients and their use of medicines.

- Training and education in ethical competence should be explicitly described as a core competency and as part of the professionalism of the pharmacist in scientific and clinical practice.

All these recommendations are held in different levels across countries. The international statements usually interfere with national traditions in pharmaceutical education, varying patients' needs and state healthcare organization. Thus each educational program in Pharmacy is unique and its strong sides can be studied and adopted by others as a part of continuous improvement process. A number of publications are devoted to the specific issue of Pharmacy curriculum (study plan) development. The innovative Backward Design approach has been used recently by Auburn University Harrison School of Pharmacy to meet the demands of future pharmacy practice (Wright et 
al., 2018). The resulting curriculum completely deviated from stand-alone courses to a series of integrating learning experiences. The existing evidence on integrating Pharmacy curriculum is summarized in the seminal paper of A.K. Husband and co-authors (Husband et al., 2014). However, the integrated pharmacy curriculum gets less attention in European countries where the competence-based learning is delivered through traditional structure of separate courses. The FARMINE report gives a precious insight into the proportion of different course areas (chemical, biological, medical, physics and mathematics, pharmaceutical technology, law, society and ethics and generic courses in study plans of 25 EU countries (Atkinson \& Rombaut, 2011).

The pharmaceutical education system in Ukraine used a common study plan defined on the state level till the 2018. The last unified Pharmacy study plan in Ukraine was approved by acting Minister of Health of Ukraine on the $26^{\text {th }}$ of July, 2016. The unified study plan represents the Ukrainian common core of pharmaceutical education. This plan remained in force till September 2018, when it was withdrawn by the Ministry of Health Order No 1696. Since in September 2018 the 2018-2019 academic year has already started in Ukraine, enrolled in 2018 students still has to follow this unified study plan. Since 2018, universities and institutions of pharmaceutical education in Ukraine were granted the right to develop study plans autonomously. The process of study plan design should take into account recent advancements in the profession and should involve different stakeholders like students, academic staff and employers. Besides that, the experience of peer universities should be studied. The best practices and ideas of foreign and domestic universities are worth to be implemented in a novel study plan. Visegrad Group (V4) countries are the closest peers for Ukraine. These countries had the similar tight state regulation of higher education in the past, but have granted autonomy for their universities much earlier than Ukraine did. That is why the experience and current design of study plans in these countries are of utmost importance for Ukrainian universities.

The purpose of this study is to compare the structure and content of Pharmacy study plans in V4 countries with the last unified Pharmacy study plan in Ukraine.

Methods The methods of bibliographic and semantic analysis, semantic grouping as well as comparative approach and synthesis were used in the study. The official documents (Pharmacy study plans, educational programs bulletins or course catalogues) found on the institution web sites were analyzed and the corresponding study courses were grouped and compared. The number of ECTS credits assigned to each study course was used as the primary indicator of the course size (educational workload). The total number of contact (auditory) hours assigned for each discipline was treated as the secondary indicator of the course size. Warsaw Medical University and Jagiellonian University in Krakow were selected as representatives of Polish institutions of pharmaceutical education. Charles University and University of Veterinary and Pharmaceutical Sciences Brno represented Czech educational traditions, Comenius University in Bratislava and University of Veterinary Medicine and Pharmacy in Kosice represented Slovak and Semmelweis University with the University of Debrecen represented pharmaceutical education in Hungary. The version of study plans that is supposed for international students and was acting during 2018-2019 academic year is used in this study. The unified Ukrainian study plan represents the study plans of pharmacists in Ukrainian universities by 2018-2019 academic year. As an example, the study plan of Uzhhorod National University for 2018-2019 academic year tightly followed this unified plan.

The Foreign Language course in V4 countries represents studying of state language of the corresponding country by foreign students, while the same course in Ukraine represents studying English, German or French. The interrelated courses were united into larger blocks in order to make the comparison meaningful.

Results and discussion There are a lot of common courses with similar workload in study plans of V4 countries and Ukraine. However, some differences are present and need to be discussed (table 1). The Ministerial study plan for pharmacists in Ukraine has three required courses in Humanity, Social and Economics section: Ukrainian lan- 
guage (for professional purposes), Ukrainian History and Culture, and Philosophy. The required character of these courses is merely a legacy from the outdated state policy on the expansion of this section into curricula of all higher education fields of study. The Law of Ukraine "On ensuring the functioning of the Ukrainian language as the state language" dated $25^{\text {th }}$ of April, 2019 requires mandatory studying of Ukrainian for all higher education programs that lead to professional degree. The Decision of National Agency for Higher Education Quality Assurance (Ukraine) dated $27^{\text {th }}$ of November, 2019 warns against the reduction of Humanity, Social and Economics components in study plans, although supports a range of approaches to guarantee proper attention to the outlook and civic responsibilities of students. There are no similar prototypes in the study plans of V4 countries. However, the direct comparison in this case is not possible since the studied V4 plans are designated for foreign students, while Ukrainian study plan is developed for domestic students.

In the majority of V4 universities the course of Molecular Biology is separated from Medical Biology or Biochemistry into the distinct mandatory component with the workload of 2-4 ECTS credits. In Ukraine this rapidly evolving science takes the small part of Biochemistry course and definitely needs to get more attention. Human Anatomy and Physiology course in Ukraine is assigned 5 ECTS credits and is somewhat limited when compared with V4 counterparts (6-16 ECTS credits). Immunology in Ukrainian study plan is just a part of Microbiology course, while universities from V4 are usually appointing 2-5 ECTS credits for mastering this science. A lot of attention in Ukraine is paid to the IT and computer skills of future pharmacists with 8 ECTS credits in total. V4 countries have more conservative position for this area and sets 2-4 or no ECTS credits for this particular purpose. Organic, analytical, physical and colloid chemistry are slightly underpowered in Ukraine in terms of ECTS credits. On the other side, there is separate Toxicological and Forensic Chemistry course taught in Ukraine. It has no counterpart in V4 study plans. Hygiene in Pharmacy and Ecology is a part of Ukrainian and Polish study plans, but this course is absent in Czech and Slovak Republics and Hungary. Life
Safety, Labor Safety, Bioethics and Biosafety are usually delivered as a short series of lectures without credit assignment. In Ukraine this complex is mandatory due to the action of Ukrainian laws requiring such courses despite declared university autonomy. Extreme Medicine course is common to Poland and Ukraine and has no obligatory status in Czech Republic, Slovak Republic or Hungary. Being the central science for pharmacists, pharmacology in Ukraine is assigned with 8.5 ECTS credits, while V4 countries usually devote from 12 to 17 ECTS credits to master this science. Medicinal, Pharmaceutical Chemistry and Pharmaceutical Analysis has less ECTS credits in Ukraine than in V4 countries, however additional obligatory course of Standardization of Medicines ( 3 ECTS credits) makes the difference not significant. There is a special course of Quality Systems in Pharmacy in Ukraine, which is rare in V4 universities, though it provides necessary introduction to good practices in manufacturing, distribution and laboratories. The last requirement is a part of FIP statement of policy on good pharmacy education practice. Medicinal Plants Resource Science is usually studied during the 9th semester in Ukrainian pharmaceutical faculties, but no counterpart was found in V4 study plans. Organization and Economics of Pharmacy, Pharmaceutical Management and Marketing are two separate courses in Ukraine, which are included as independent subtests of State Testing Exam for pharmacists. They are provided with 12 ECTS credits in sum, while universities in V4 countries are planning them usually as a single course with 2-7 ECTS credits. Pharmaceutical and Medical Commodity Science is present as an obligatory part of training only in Ukrainian universities, Charles University and in the University of Veterinary Medicine and Pharmacy in Kosice. It is worth to mention the obligatory course of Clinical Biochemistry or Pathobiochemistry being taught in Warsaw and Krakow, Prague, Bratislava, Kosice and Budapest. Ukrainian study plans usually allocate the similar course of Functional Biochemistry in the elective section, which may be chosen or not by pharmacy students. The idea of transferring Functional Biochemistry to the section of obligatory courses is worth discussing. Military Officers in Pharmacy Field Train- 
ing course was introduced to the Ukrainian study plans by the joint Order of Ministry of Defense, Ministry of Health and Ministry of Education and Science of Ukraine No 322/631/709 dated 29th June 2016. It slightly correlates with Principles of Dosimetry and Radiation Protection course offered in Charles University and has no direct counterpart. However, only Ukraine poses the threat of full-blown war and needs special attention to military topics in the Pharmacy education. While the Ukrainian unified study plan mentions the possibility to prepare and to defend master's thesis for graduation, it does not grant mandatory status for thesis preparation and it does not allocate ECTS credits for this educational efforts. All universities in V4 countries require students scientific work on thesis preparation and further defense. The corresponding number of ECTS credits are allocated and assigned for this. Instead of thesis preparation, the educational plans in Ukraine contain a series of course papers (prepared in each major study discipline).

Table 1. Comparative analysis of Pharmacy study plan components with corresponding ECTS credits (contact hours) in V4 countries and Ukraine*

\begin{tabular}{|c|c|c|c|c|c|c|c|c|c|}
\hline Course & 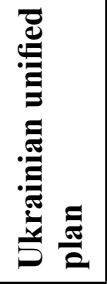 & 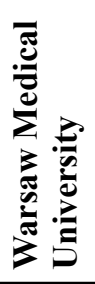 & 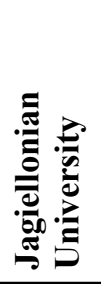 & 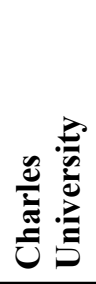 & 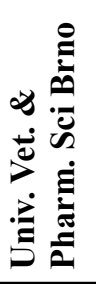 & 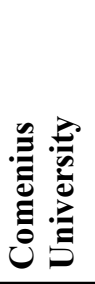 & 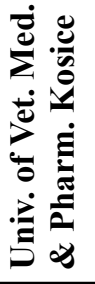 & 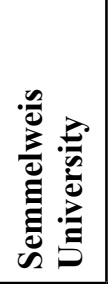 & 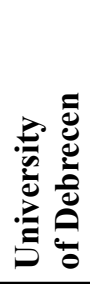 \\
\hline $\begin{array}{r}\text { Language of Study (for professional } \\
\text { purposes) }\end{array}$ & $\begin{array}{c}3 \\
(30) \\
\end{array}$ & - & - & - & - & - & - & - & - \\
\hline National History and Culture & $\begin{array}{c}3 \\
(30)\end{array}$ & - & - & - & - & - & - & - & - \\
\hline Philosophy & $\begin{array}{c}3 \\
(40)\end{array}$ & $\begin{array}{c}1 \\
(15) \\
\end{array}$ & $\begin{array}{c}1 \\
(15)\end{array}$ & - & - & - & - & - & - \\
\hline $\begin{array}{r}\text { Foreign Language (for professional pur- } \\
\text { poses) }\end{array}$ & $\begin{array}{c}6 \\
(80)\end{array}$ & $\begin{array}{c}3 \\
(60) \\
\end{array}$ & $\begin{array}{c}6 \\
(180)\end{array}$ & $\begin{array}{l}3 \\
(-)\end{array}$ & $\begin{array}{c}2 \\
(28)\end{array}$ & - & $\begin{array}{c}4 \\
(56)\end{array}$ & $\begin{array}{c}12 \\
(280)\end{array}$ & $\begin{array}{c}12 \\
(200)\end{array}$ \\
\hline Higher Mathematics and Statistics & $\begin{array}{l}3.5 \\
(70)\end{array}$ & $\begin{array}{c}7 \\
(105)\end{array}$ & $\begin{array}{c}5 \\
(75)\end{array}$ & $\begin{array}{c}3 \\
(48)\end{array}$ & - & $\begin{array}{c}4 \\
(42)\end{array}$ & $\begin{array}{c}3 \\
(56)\end{array}$ & $\begin{array}{c}7 \\
(98)\end{array}$ & $\begin{array}{c}5 \\
(56)\end{array}$ \\
\hline $\begin{array}{r}\text { Physics, Biological Physics and Physical } \\
\text { Methods of Analysis }\end{array}$ & $\begin{array}{c}4.5 \\
(80) \\
\end{array}$ & $\begin{array}{c}2 \\
(30) \\
\end{array}$ & $\begin{array}{c}3 \\
(30) \\
\end{array}$ & $\begin{array}{c}4 \\
(42) \\
\end{array}$ & $\begin{array}{c}3 \\
(28) \\
\end{array}$ & $\begin{array}{c}5 \\
(56) \\
\end{array}$ & $\begin{array}{c}6 \\
(56) \\
\end{array}$ & $\begin{array}{c}10 \\
(140) \\
\end{array}$ & $\begin{array}{c}9 \\
(84) \\
\end{array}$ \\
\hline Biology and Genetics & $\begin{array}{c}4 \\
(70)\end{array}$ & $\begin{array}{c}4 \\
(60)\end{array}$ & $\begin{array}{c}6 \\
(60)\end{array}$ & $\begin{array}{c}7 \\
(70)\end{array}$ & $\begin{array}{c}5 \\
(56)\end{array}$ & $\begin{array}{c}4 \\
(42)\end{array}$ & $\begin{array}{c}7 \\
(56)\end{array}$ & $\begin{array}{c}7 \\
(112)\end{array}$ & $\begin{array}{c}10 \\
(112)\end{array}$ \\
\hline Molecular Biology & - & $\begin{array}{c}2 \\
(15) \\
\end{array}$ & $\begin{array}{c}3 \\
(40) \\
\end{array}$ & $\begin{array}{c}3 \\
(28) \\
\end{array}$ & $\begin{array}{c}2 \\
(28) \\
\end{array}$ & - & $\begin{array}{c}4 \\
(56) \\
\end{array}$ & - & - \\
\hline Human Anatomy and Physiology & $\begin{array}{c}5 \\
(100) \\
\end{array}$ & $\begin{array}{c}7 \\
(105) \\
\end{array}$ & $\begin{array}{c}13 \\
(120) \\
\end{array}$ & $\begin{array}{c}8 \\
(84) \\
\end{array}$ & $\begin{array}{c}9 \\
(84) \\
\end{array}$ & $\begin{array}{c}6 \\
(70) \\
\end{array}$ & $\begin{array}{c}12 \\
(126) \\
\end{array}$ & $\begin{array}{c}16 \\
(224) \\
\end{array}$ & $\begin{array}{c}13 \\
(168)\end{array}$ \\
\hline Pathophysiology & $\begin{array}{c}5 \\
(80)\end{array}$ & $\begin{array}{c}5 \\
(75)\end{array}$ & $\begin{array}{c}6 \\
(75)\end{array}$ & $\begin{array}{c}7 \\
(70)\end{array}$ & $\begin{array}{c}6 \\
(56)\end{array}$ & $\begin{array}{c}5 \\
(56)\end{array}$ & $\begin{array}{c}6 \\
(70)\end{array}$ & $\begin{array}{c}4 \\
(56)\end{array}$ & - \\
\hline Latin Language & $\begin{array}{c}3 \\
(60) \\
\end{array}$ & $\begin{array}{c}2 \\
(60) \\
\end{array}$ & $\begin{array}{c}2 \\
(60) \\
\end{array}$ & $\begin{array}{c}3 \\
(28) \\
\end{array}$ & $\begin{array}{c}4 \\
(42) \\
\end{array}$ & $\begin{array}{c}4 \\
(56) \\
\end{array}$ & $\begin{array}{c}3 \\
(56) \\
\end{array}$ & $\begin{array}{c}2 \\
(28) \\
\end{array}$ & $\begin{array}{c}2 \\
(56) \\
\end{array}$ \\
\hline Immunology & - & $\begin{array}{c}2 \\
(30) \\
\end{array}$ & $\begin{array}{c}3 \\
(45) \\
\end{array}$ & $\begin{array}{c}4 \\
(56) \\
\end{array}$ & - & $\begin{array}{c}4 \\
(42) \\
\end{array}$ & $\begin{array}{c}5 \\
(56)\end{array}$ & $\begin{array}{c}2 \\
(21)\end{array}$ & $\begin{array}{c}4 \\
(37)\end{array}$ \\
\hline Microbiology & $\begin{array}{c}5 \\
(90)\end{array}$ & $\begin{array}{c}5 \\
(90)\end{array}$ & $\begin{array}{c}8 \\
(105)\end{array}$ & $\begin{array}{c}4 \\
(42)\end{array}$ & $\begin{array}{c}5 \\
(56)\end{array}$ & $\begin{array}{c}4 \\
(42)\end{array}$ & $\begin{array}{c}6 \\
(56)\end{array}$ & $\begin{array}{c}5 \\
(70)\end{array}$ & $\begin{array}{c}10 \\
(76)\end{array}$ \\
\hline $\begin{array}{r}\text { Computer Modeling in Pharmacy, } \\
\text { Information Technologies }\end{array}$ & $\begin{array}{c}8 \\
(110)\end{array}$ & $\begin{array}{c}2 \\
(30)\end{array}$ & $\begin{array}{c}2 \\
(45)\end{array}$ & - & - & - & $\begin{array}{c}3 \\
(56)\end{array}$ & $\begin{array}{c}4 \\
(56)\end{array}$ & - \\
\hline
\end{tabular}




\begin{tabular}{|c|c|c|c|c|c|c|c|c|c|}
\hline General and Inorganic Chemistry & $\begin{array}{c}6 \\
(110) \\
\end{array}$ & $\begin{array}{c}13 \\
(180)\end{array}$ & $\begin{array}{c}12 \\
(150)\end{array}$ & $\begin{array}{c}4 \\
(42) \\
\end{array}$ & $\begin{array}{c}8 \\
(84) \\
\end{array}$ & $\begin{array}{c}8 \\
(98) \\
\end{array}$ & $\begin{array}{c}9 \\
(98) \\
\end{array}$ & $\begin{array}{c}13 \\
(182) \\
\end{array}$ & $\begin{array}{c}8 \\
(112) \\
\end{array}$ \\
\hline Organic Chemistry & $\begin{array}{c}8 \\
(150)\end{array}$ & $\begin{array}{c}17 \\
(225)\end{array}$ & $\begin{array}{c}13 \\
(210)\end{array}$ & $\begin{array}{c}11 \\
(104)\end{array}$ & $\begin{array}{c}10 \\
(126)\end{array}$ & $\begin{array}{c}12 \\
(140)\end{array}$ & $\begin{array}{c}15 \\
(140)\end{array}$ & $\begin{array}{c}19 \\
(266)\end{array}$ & $\begin{array}{c}13 \\
(224)\end{array}$ \\
\hline Analytical Chemistry & $\begin{array}{c}8 \\
(150) \\
\end{array}$ & $\begin{array}{c}13 \\
(180) \\
\end{array}$ & $\begin{array}{c}13 \\
(180) \\
\end{array}$ & $\begin{array}{c}9 \\
(126) \\
\end{array}$ & $\begin{array}{c}10 \\
(140)\end{array}$ & $\begin{array}{c}15 \\
(182) \\
\end{array}$ & $\begin{array}{c}12 \\
(168) \\
\end{array}$ & $\begin{array}{c}19 \\
(294)\end{array}$ & $\begin{array}{c}16 \\
(266) \\
\end{array}$ \\
\hline Physical and Colloid Chemistry & $\begin{array}{c}4 \\
(90) \\
\end{array}$ & $\begin{array}{c}7 \\
(105) \\
\end{array}$ & $\begin{array}{c}11 \\
(105) \\
\end{array}$ & $\begin{array}{c}5 \\
(56) \\
\end{array}$ & $\begin{array}{c}6 \\
(56) \\
\end{array}$ & $\begin{array}{c}7 \\
(84) \\
\end{array}$ & $\begin{array}{c}8 \\
(84) \\
\end{array}$ & $\begin{array}{c}13 \\
(182) \\
\end{array}$ & $\begin{array}{c}9 \\
(140) \\
\end{array}$ \\
\hline $\begin{array}{r}\text { Pharmaceutical Botany (with Botany } \\
\text { Practice) }\end{array}$ & $\begin{array}{c}8 \\
(120) \\
\end{array}$ & $\begin{array}{c}6 \\
(90) \\
\end{array}$ & $\begin{array}{c}9 \\
(90) \\
\end{array}$ & $\begin{array}{c}8 \\
(112) \\
\end{array}$ & $\begin{array}{c}9 \\
(112) \\
\end{array}$ & $\begin{array}{c}6 \\
(70) \\
\end{array}$ & $\begin{array}{c}6 \\
(56) \\
\end{array}$ & $\begin{array}{c}7 \\
(98) \\
\end{array}$ & $\begin{array}{c}3 \\
(56) \\
\end{array}$ \\
\hline Biological Chemistry & $\begin{array}{c}6 \\
(100) \\
\end{array}$ & $\begin{array}{c}6 \\
(90) \\
\end{array}$ & $\begin{array}{c}10 \\
(105) \\
\end{array}$ & $\begin{array}{c}8 \\
(98)\end{array}$ & $\begin{array}{c}6 \\
(56) \\
\end{array}$ & $\begin{array}{c}8 \\
(98) \\
\end{array}$ & $\begin{array}{c}6 \\
(98) \\
\end{array}$ & $\begin{array}{c}6 \\
(98) \\
\end{array}$ & $\begin{array}{c}10 \\
(82)\end{array}$ \\
\hline Hygiene in Pharmacy and Ecology & $\begin{array}{c}3 \\
(40) \\
\end{array}$ & $\begin{array}{c}2 \\
(30) \\
\end{array}$ & $\begin{array}{c}2 \\
(30) \\
\end{array}$ & - & - & - & - & - & - \\
\hline Pharmaceutical Law and Ethics & $\begin{array}{c}6 \\
(90) \\
\end{array}$ & $\begin{array}{c}2 \\
(30)\end{array}$ & $\begin{array}{c}4 \\
(60)\end{array}$ & $\begin{array}{c}2 \\
(28)\end{array}$ & $\begin{array}{c}4 \\
(42) \\
\end{array}$ & - & $\begin{array}{c}3 \\
(28)\end{array}$ & $\begin{array}{c}2 \\
(35)\end{array}$ & - \\
\hline $\begin{array}{r}\text { Pharmaceutical Technology, Cosmetics } \\
\text { Technology, Biopharmaceutics } \\
\end{array}$ & $\begin{array}{c}18 \\
(300) \\
\end{array}$ & $\begin{array}{c}21 \\
(375) \\
\end{array}$ & $\begin{array}{c}23 \\
(375) \\
\end{array}$ & $\begin{array}{c}19 \\
(280) \\
\end{array}$ & $\begin{array}{c}20 \\
(294) \\
\end{array}$ & $\begin{array}{c}20 \\
(252)\end{array}$ & $\begin{array}{c}10 \\
(252)\end{array}$ & $\begin{array}{c}35 \\
(574) \\
\end{array}$ & $\begin{array}{c}25 \\
(532) \\
\end{array}$ \\
\hline Pharmaceutical Biotechnology & $\begin{array}{c}3 \\
(50) \\
\end{array}$ & $\begin{array}{c}2 \\
(30) \\
\end{array}$ & $\begin{array}{c}3 \\
(30) \\
\end{array}$ & - & - & - & - & - & $\begin{array}{c}5 \\
(28) \\
\end{array}$ \\
\hline $\begin{array}{r}\text { Life Safety, Labor Safety, Bioethics and } \\
\text { Biosafety }\end{array}$ & $\begin{array}{c}6 \\
(80) \\
\end{array}$ & $\begin{array}{c}- \\
(4)\end{array}$ & - & - & - & - & - & - & $\begin{array}{c}1 \\
(28) \\
\end{array}$ \\
\hline $\begin{array}{r}\text { Extreme Medicine and Military Officers in } \\
\text { Pharmacy Field Training }\end{array}$ & $\begin{array}{c}6 \\
(80)\end{array}$ & $\begin{array}{c}2 \\
(30)\end{array}$ & $\begin{array}{c}2 \\
(30)\end{array}$ & $\begin{array}{c}1 \\
(14)\end{array}$ & - & - & - & - & - \\
\hline $\begin{array}{r}\text { Introduction to Pharmacy Practice (History } \\
\text { of Pharmacy) }\end{array}$ & $\begin{array}{c}3 \\
(60) \\
\end{array}$ & $\begin{array}{c}1 \\
(15) \\
\end{array}$ & $\begin{array}{c}2 \\
(30) \\
\end{array}$ & $\begin{array}{c}5 \\
(59) \\
\end{array}$ & $\begin{array}{c}6 \\
(70) \\
\end{array}$ & $\begin{array}{c}2 \\
(28) \\
\end{array}$ & - & $\begin{array}{c}2 \\
(28) \\
\end{array}$ & $\begin{array}{c}2 \\
(14)\end{array}$ \\
\hline Pharmacognosy & $\begin{array}{c}11.5 \\
(200)\end{array}$ & $\begin{array}{c}11 \\
(150) \\
\end{array}$ & $\begin{array}{c}11 \\
(150) \\
\end{array}$ & $\begin{array}{c}10 \\
(140) \\
\end{array}$ & $\begin{array}{c}14 \\
(182) \\
\end{array}$ & $\begin{array}{c}14 \\
(168) \\
\end{array}$ & $\begin{array}{c}14 \\
(154) \\
\end{array}$ & $\begin{array}{c}12 \\
(168) \\
\end{array}$ & $\begin{array}{c}12 \\
(168) \\
\end{array}$ \\
\hline $\begin{array}{r}\text { Pharmacotherapy, Clinical Pharmacy, } \\
\text { Pharmacokinetics }\end{array}$ & $\begin{array}{c}12 \\
(190) \\
\end{array}$ & $\begin{array}{c}10 \\
(150)\end{array}$ & $\begin{array}{c}14 \\
(160) \\
\end{array}$ & $\begin{array}{c}22 \\
(267) \\
\end{array}$ & $\begin{array}{c}10 \\
(132)\end{array}$ & $\begin{array}{c}11 \\
(126) \\
\end{array}$ & $\begin{array}{c}5 \\
(70) \\
\end{array}$ & $\begin{array}{c}8 \\
(126) \\
\end{array}$ & $\begin{array}{c}9 \\
(126) \\
\end{array}$ \\
\hline Pharmacology & $\begin{array}{c}8.5 \\
(170) \\
\end{array}$ & $\begin{array}{c}17 \\
(210) \\
\end{array}$ & $\begin{array}{c}15 \\
(240) \\
\end{array}$ & $\begin{array}{c}14 \\
(216) \\
\end{array}$ & $\begin{array}{c}14 \\
(168) \\
\end{array}$ & $\begin{array}{c}14 \\
(168) \\
\end{array}$ & $\begin{array}{c}17 \\
(154) \\
\end{array}$ & $\begin{array}{c}12 \\
(168) \\
\end{array}$ & $\begin{array}{c}12 \\
(224) \\
\end{array}$ \\
\hline $\begin{array}{r}\text { Medicinal, Pharmaceutical Chemistry and } \\
\text { Pharmaceutical Analysis }\end{array}$ & $\begin{array}{c}13 \\
(250) \\
\end{array}$ & $\begin{array}{c}19 \\
(255)\end{array}$ & $\begin{array}{c}15 \\
(255) \\
\end{array}$ & $\begin{array}{c}22 \\
(308) \\
\end{array}$ & $\begin{array}{c}24 \\
(260) \\
\end{array}$ & $\begin{array}{c}19 \\
(224)\end{array}$ & $\begin{array}{c}19 \\
(224)\end{array}$ & $\begin{array}{c}22 \\
(336) \\
\end{array}$ & $\begin{array}{c}29 \\
(364) \\
\end{array}$ \\
\hline Quality Systems in Pharmacy & $\begin{array}{c}3 \\
(50) \\
\end{array}$ & - & - & - & - & - & - & - & $\begin{array}{c}2 \\
(28) \\
\end{array}$ \\
\hline Standardization of Medicines & $\begin{array}{c}3 \\
(50) \\
\end{array}$ & - & - & - & - & - & - & - & - \\
\hline $\begin{array}{r}\text { Pharmacoeconomics, Social Pharmacy, } \\
\text { Pharmacovigilance }\end{array}$ & $\begin{array}{c}6 \\
(70) \\
\end{array}$ & - & $\begin{array}{c}2 \\
(30)\end{array}$ & $\begin{array}{c}6 \\
(56)\end{array}$ & $\begin{array}{c}4 \\
(42)\end{array}$ & $\begin{array}{c}5 \\
(56)\end{array}$ & $\begin{array}{c}4 \\
(56)\end{array}$ & $\begin{array}{c}4 \\
(56)\end{array}$ & $\begin{array}{c}5 \\
(114) \\
\end{array}$ \\
\hline Medicinal Plants Resource Science & $\begin{array}{c}3 \\
(50)\end{array}$ & - & - & - & - & - & - & - & - \\
\hline $\begin{array}{l}\text { Organization and Economics of Pharmacy, } \\
\text { Pharmaceutical Management and Marketing }\end{array}$ & $\begin{array}{c}12 \\
(200) \\
\end{array}$ & $\begin{array}{c}4 \\
(60) \\
\end{array}$ & $\begin{array}{c}2 \\
(30) \\
\end{array}$ & $\begin{array}{c}5 \\
(38) \\
\end{array}$ & $\begin{array}{c}4 \\
(56)\end{array}$ & $\begin{array}{c}5 \\
(56) \\
\end{array}$ & $\begin{array}{c}7 \\
(98) \\
\end{array}$ & $\begin{array}{c}6 \\
(84)\end{array}$ & $\begin{array}{c}2 \\
(28) \\
\end{array}$ \\
\hline $\begin{array}{r}\text { Pharmaceutical and Medical Commodity } \\
\text { Science } \\
\end{array}$ & $\begin{array}{c}4 \\
(50) \\
\end{array}$ & - & - & $\begin{array}{c}2 \\
(28) \\
\end{array}$ & - & - & $\begin{array}{c}3 \\
(28) \\
\end{array}$ & - & - \\
\hline $\begin{array}{r}\text { Toxicology and Pharmacogenomics, } \\
\text { Interaction of Drugs } \\
\end{array}$ & $\begin{array}{c}3 \\
(40) \\
\end{array}$ & $\begin{array}{c}8 \\
(120) \\
\end{array}$ & $\begin{array}{c}7 \\
(90) \\
\end{array}$ & $\begin{array}{c}2 \\
(28)\end{array}$ & $\begin{array}{c}4 \\
(42) \\
\end{array}$ & - & $\begin{array}{c}8 \\
(70) \\
\end{array}$ & - & $\begin{array}{c}4 \\
(28) \\
\end{array}$ \\
\hline Toxicological and Forensic Chemistry & $\begin{array}{c}4 \\
(90) \\
\end{array}$ & - & - & - & - & - & - & - & - \\
\hline First Aid and Introductory Medical Practice & $\begin{array}{c}3 \\
(50)\end{array}$ & $\begin{array}{c}2 \\
(45)\end{array}$ & $\begin{array}{c}1 \\
(15)\end{array}$ & $\begin{array}{c}1 \\
(14)\end{array}$ & $\begin{array}{c}2 \\
(28)\end{array}$ & - & - & $\begin{array}{c}- \\
(14)\end{array}$ & - \\
\hline
\end{tabular}




\begin{tabular}{|c|c|c|c|c|c|c|c|c|c|}
\hline $\begin{array}{r}\text { Pharmaceutical practice and Thesis } \\
\text { Preparation }\end{array}$ & 33 & 65 & 60 & 77 & 52 & 64 & 57 & 47 & 26 \\
\hline $\begin{aligned} \text { Elective Courses } \\
\end{aligned}$ & 42 & 30 & 21 & 7 & 55 & 43 & 24 & 6 & 60 \\
\hline Psychology with Sociology & - & $\begin{array}{c}1 \\
(15)\end{array}$ & $\begin{array}{c}1 \\
(15)\end{array}$ & $\begin{array}{c}1 \\
(14)\end{array}$ & - & - & - & - & $\begin{array}{c}2 \\
(28)\end{array}$ \\
\hline Metabolism of Drugs & - & $\begin{array}{c}1 \\
(15)\end{array}$ & - & - & - & - & - & - & - \\
\hline $\begin{array}{r}\text { Clinical Biochemistry and } \\
\text { Pathobiochemistry }\end{array}$ & - & $\begin{array}{c}3 \\
(45)\end{array}$ & $\begin{array}{c}2 \\
(30)\end{array}$ & $\begin{array}{c}3 \\
(28)\end{array}$ & - & $\begin{array}{c}4 \\
(42) \\
\end{array}$ & $\begin{array}{c}4 \\
(56)\end{array}$ & - & $\begin{array}{c}12 \\
(134) \\
\end{array}$ \\
\hline Bromatology & - & $\begin{array}{c}5 \\
(75) \\
\end{array}$ & $\begin{array}{c}4 \\
(75)\end{array}$ & - & - & - & - & - & - \\
\hline Synthesis and Technology of Drugs & - & $\begin{array}{c}5 \\
(75)\end{array}$ & $\begin{array}{c}6 \\
(75)\end{array}$ & - & - & - & - & - & - \\
\hline Natural Drugs & - & $\begin{array}{c}2 \\
(30)\end{array}$ & $\begin{array}{c}3 \\
(30)\end{array}$ & $\begin{array}{c}3 \\
(14)\end{array}$ & - & - & - & - & - \\
\hline Intelectual Property & - & - & $\begin{array}{c}1 \\
(15)\end{array}$ & - & - & - & - & - & - \\
\hline Scientific Information on Drugs & - & - & $\begin{array}{c}1 \\
(15)\end{array}$ & - & - & - & - & - & - \\
\hline Chemical Laboratory Technique & - & - & - & $\begin{array}{c}3 \\
(70)\end{array}$ & - & - & - & - & - \\
\hline Communication Skills for Pharmacists & - & - & - & $\begin{array}{c}2 \\
(28)\end{array}$ & - & - & - & - & $\begin{array}{c}2 \\
(28)\end{array}$ \\
\hline Veterinary Drugs & - & - & - & $\begin{array}{c}2 \\
(28)\end{array}$ & - & - & $\begin{array}{c}4 \\
(56)\end{array}$ & - & - \\
\hline Phytochemistry & - & - & - & - & $\begin{array}{c}3 \\
(28)\end{array}$ & - & - & - & - \\
\hline Radiopharmaceuticals & - & - & - & - & - & $\begin{array}{c}4 \\
(42) \\
\end{array}$ & $\begin{array}{c}2 \\
(42)\end{array}$ & - & $\begin{array}{c}2 \\
(28)\end{array}$ \\
\hline Pharmaceutical Neurobiology & - & - & - & - & - & - & - & - & $\begin{array}{c}3 \\
(70) \\
\end{array}$ \\
\hline Clinical Basics & - & - & - & - & - & - & - & - & $\begin{array}{c}3 \\
(84)\end{array}$ \\
\hline
\end{tabular}

*The courses are marked with blue when they are significantly overloaded in Ukrainian study plan and the courses are marked with orange when they are significantly underloaded in Ukrainian study plan as compared to V4 peers.

Current analysis identifies some differences in study plans in V4 countries and Ukraine. This differences do not obviously lead to some gaps in general or professional competences and program outcomes, since there are a number of ways to achieve the same results throughout the curriculum. The second limitation of the study raises from the fuzzy meaning of ECTS credits as a measure of learning content width and depth. In fact, we are comparing the number of ECTS credits assigned to the same courses, while this number does not reflect the size of the course accurately. This issue is supported by the broad range of contact (auditory) hours assigned to the courses with the same number ECTS credits. Cases when the course with less ECTS credits has higher number of contact hours are common both in Ukrainian and V4 study plans. The third issue belongs to course syllabi in different countries and universities. They can differ significantly while maintaining the same number of ECTS credits.

Conclusions As a general outline, the Pharmacy study plans of V4 universities show greater similarity with each other and tend to differ from the Ukrainian unified study plan. The necessary steps to harmonize Pharmacy study plans of Ukrainian universities with V4 countries include the introduction of Molecular Biology, Immunol- 
ogy, Clinical Biochemistry courses, and strengthening the basic medical and chemical science courses like Human Anatomy and Physiology, Organic Chemistry, Analytical Chemistry, Physical and Colloid Chemistry, Pharmacology and Medicinal and Pharmaceutical Chemistry. Using the results of the study, Uzhhorod National University has already implemented several changes into their pharmacy study plan in order to made a step closer to the V4 countries academic documents. These changes include deletion of study modules "Medical parasitology" and "Medical arachnoentomology. Biosphere and human" from the Biology and Genetics course and reorganization of this course into the "Cell, Molecular Biology and Genetics". In this way the Molecular Biology has got proper attention in the study plan. Courses of National History and Culture and Philosophy were reorganized into the more practical Civil Education course. Physical methods of analysis were transferred to the Analytical Chemistry course. The number of ECTS credits and contact hours assigned to Toxicological and Forensic Chemistry underwent shortening while
Pharmacotherapy course has been expanded. Inspired by the example of several foreign universities, the splitting of Pharmaceutical Chemistry into Pharmaceutical Chemistry (dealing with pharmaceutical synthesis and analysis) and Medicinal Chemistry (dealing with structure-activity relationships and the search of new medicines) has been performed. It is worth to note that any change in study plans should be supported with the broad discussion of the proposals with key stakeholders. And the introduction of new courses or expansion of the existent courses should not be mechanistical: thorough analysis of corresponding syllabi, preparation of learning content, learning cases and practical tasks together with assessment instruments are crucial to assure Pharmacy education of high quality. The comparative analysis of Ukrainian and V4 countries pharmaceutical courses syllabi is the promising direction of further research efforts. Such analysis may improve and strengthen our approaches to deliver high quality pharmaceutical education to willing students.

Funding This study has no external funding.

\section{REFERENCES}

Anderson, C., Bates, I., Beck, D., Brock, T. P., Futter, B., Mercer, H., Rouse, M., Whitmarsh, S., Wuliji, T., \& Yonemura, A. (2009). The WHO UNESCO FIP pharmacy education taskforce. Human Resources for Health, 7(1), 1-8.

Anderson, C., Bates, I., Brock, T., Brown, A., Bruno, A., Gal, D., Galbraith, K., Marriott, J., Rennie, T., \& Rouse, M. J. (2014). Highlights from the FIPEd global education report. American Journal of Pharmaceutical Education, 78(1).

Atkinson, J., \& Rombaut, B. (2011). The 2011 PHARMINE report on pharmacy and pharmacy education in the European Union. Pharmacy Practice, 9(4), 169-187. https://doi.org/10.4321/s1886-36552011000400001

European Parliament. (2005). Directive 2005/36/EC of the European Parliament and of the Council of 7 September 2005 on the recognition of professional qualifications (text with EEA relevance). Off J Eur Union, 255, $22-142$.

Federation, I. P. (2000). FIP statement of policy on good pharmacy education practice.

Husband, A. K., Todd, A., \& Fulton, J. (2014). Integrating science and practice in pharmacy curricula. American Journal of Pharmaceutical Education, 78(3).

Law, M., Bader, L., Uzman, N., Williams, A., \& Bates, I. (2019). The FIP Nanjing Statements: Shaping global pharmacy and pharmaceutical sciences education. Research in Social and Administrative Pharmacy, 15(12), $1472-1475$.

Wright, B. M., Hornsby, L., Marlowe, K. F., Fowlin, J., \& Surry, D. W. (2018). Innovating Pharmacy Curriculum through Backward Design. TechTrends, 62(3), 224-229. https://doi.org/10.1007/s11528-018-0283-8 


\section{НАВЧАЛЬНІ ПЛАНИ 3 ФАРМАЦІЇ У КРАЇНАХ ВИШЕГРАДСЬКОЇ ЧЕТВІРКИ ТА В УКРАЇНI: ПОРІВНЯЛЬНИЙ АНАЛІЗ}

\author{
Девіняк Олег, Стан Ірина, Сятиня \\ Вікторія, Деяк Ярослава, Литвин \\ Олена, Качур Іван \\ ДВНЗ «Ужгородський національний \\ університет», Україна
}

Анотація. Грунтовний підхід до складання навчальних планів $є$ ключовим елементом будь-якої успішної освітньої програми. До 2018 року Міністерство охорони здоров'я України регулювало структуру навчальних планів $з$ фармації шляхом прийняття єдиного примірного навчального плану на рівні Міністерства. На теперішній час відповідальність за розробку освітніх програм та відповідних навчальних планів в Україні повністю передано університетам. Метою цього дослідження $\epsilon$ порівняння структури та змісту навчальних планів 3 фармації в країнах Вишеградської групи із останнім типовим навчальним планом $з$ фармації в Україні. Методи. Для аналізу використовували офіційні документи Варшавського медичного університету, Ягеллонського університету в Кракові, Карлового університету, Університету ветеринарних та фармацевтичних наук Брно, Університету Коменського, Університету ветеринарної медицини та фармації в Кошице, Університету Земмельвейса та Дебреценського університету, 3 яких отримано необхідні дані про навчальні дисципліни та відповідні кредити ECTS. Проведено порівняння структури іноземних та українського примірного навчального плану. Результати. Український примірний навчальний план 3 фармації значно більше уваги приділяе дисциплінам гуманітарного та соціально-економічного блоку (9 кредитів ECTS плюс 6 кредитів ECTS іноземної мови), навичкам роботи 3 комп'ютером та IT (8 кредитів ECTS), гігієні та екології (3 кредити ЕСТS), безпеці життедіяльності, охороні праці та біоетиці (загалом 6 кредитів ЕСТS), екстремальній медицині та військовій підготовці (загалом 6 кредитів ЕCTS), токсикологічній та судовій хімії (4 кредити ЕCTS), організації та економіці фармації, фармацевтичному менеджменту та маркетингу (загалом 12 кредитів ECTS) порівняно із закордонними університетами. У той час як природничі дисципліни отримують менше кредитів ECTS в Україні, а окремі дисципліни, які представляють сучасні динамічні науки: молекулярна біологія, імунологія чи клінічна біохімія, - примірним навчальним планом не передбачені. Висновки. Навчальні плани 3 фармації в університетах Вишеградської четвірки демонструють більшу схожість між собою і дещо відрізняються від українського примірного навчального плану, схваленого Міністерством охорони здоров'я у 2016. Необхідні кроки для гармонізації навчальних планів українських університетів 3 країнами Вишеградської четвірки включають запровадження курсів молекулярної біології, імунології, клінічної біохімії та посилення базових курсів медичних та хімічних наук, таких як анатомія та фізіологія людини, органічна хімія, аналітична хімія, фармакологія, фармацевтична хімія та хімія лікарських засобів.

Ключові слова: навчальні плани, дизайн навчальних планів, фармацевтична освіта, країни Вишеградської четвірки, кредити ECTS. 